\title{
Action and emotion in speaking
}

\section{F. H. Lane}

To cite this article: F. H. Lane (1916) Action and emotion in speaking, Quarterly Journal of Speech, 2:3, 221-228, DOI: 10.1080/00335631609360544

To link to this article: http://dx.doi.org/10.1080/00335631609360544

曲 Published online: 05 Jun 2009.

Submit your article to this journal

山 Article views: 12

Q View related articles $₫$ 


\title{
THE QUARTERLY JOURNAL of Public Speaking
}

\author{
JULY, 1916 \\ ACTION AND EMOTION IN SPEAKING
}

F. H. LANE

University of Pittsburgh

\begin{abstract}
$\mathrm{A}^{\mathrm{s}}$
TEACHERS of Public Speaking we are bound to realize that action and emotion are closely related. We know that pleasurable experiences manifest themselves in large expansive movements and that painful experiences reveal themselves in shrinking movements. There needs no psychologist come from the laboratory to tell us that each emotion has its characteristic motor conditions. We must know too from our study of speakers and from our observation of students that as a general rule men who feel deeply on a subjeet express themselves by abundant gesticulation, unless they keep a tight rein upon their emotions. The trait is, of course, not merely individual, it is national and racial as well. Lord Curzon says that the foreigner who is accustomed to see the legislators of his own country rush up and down the stage and throw their arms wildly about, is astonished to behold the calmness of the English Parliamentarians.

I believe that the public speakers may pass through three stages with reference to emotional expression and that different ages and different races probably pass through the same three stages. Of course, when we come to consider nations and periods we must look broadly at the drift of things.

I will start the discussion by reference to three examples. I know rather well the little four and a half year old daughter of one of my colleagues. She tells the story of Lot's wife with abundant action and interesting variation. When she refers to the many, many wicked people and cities, she spreads out her hands, and when
\end{abstract}


she comes to the place where Lot's wife looks back, her face becomes animated, her whole body expresses enthusiasm, and she lifts her hands above her head and exclaims, "And Lot's wife was turned into a pillar of butter." Her mother had told her the incident simply and had not even hinted the gestures to her. She had perfect self-forgetfulness and abandonment, not because she was thinking of Lot's wife, for she hardly understood a word of the story, but because she was expressing her own emotion.

My second example is that of a man who is the author of a number of books and who often makes speeches. Some years ago I had the fortune to hear him address a college audience and to learn how the students regarded what he said. His whole body was active, his arms jerked, he shrugged his shoulders, he brought his hand frequently to his mouth, he stood awkardly and leaned on the desk,-almost any action that had no particular connection with what he was saying. When he had finished speaking, the students cheered him to the echo, but when they talked among themselves, they referred to the address as a "Fourth of July affair," and the senior who was to report it to the college paper declared that it was so incoherent that he could see little but idiosyncrasies and bits of personal vanity. It appears that selfconsciousness and egotism may do something to obscure a speaker's theme.

As a third example I refer to a man who makes two or three speeches a week to somewhat varied audiences. When I mentioned my present subject to him and asked him what he thought of the theme, he replied that he himself used no gestures. I jokingly reminded him that he was not properly energized. I hastened to add, however, that the themes on which he was speaking were largely such as appeal to what William James calls the finer emotions and that the prompting to action was not so strong as in the case of the coarser emotions. Further I told him that I was using action in its broadest significance. In the term $I$ included the frown, the smile, the flash of eyes, and the change of bearing. And then I told him that I should have to contradict his statement that he used no gestures, for $\mathbb{I}$ had often seen him use the more quiet forms of action. His speeches are always well organized, logical and symmetrical; one might almost say that he plans addresses as Tybalt fights,- by a book in arithmetic, one, two, three, and the idea in your bosom. 
In these three examples we have progressed from much feeling and frequent action with little thought to deliberate plan and perfectly controlled action of a subdued character. Of course, some speakers never get beyond the first stages, but do not many speakers pass through the development which I have sketched in these instances?

Let us look at the question first from the point of view of the stage. William James tells us that any voluntary cold-blooded arousal of the so-called manifestations of a special emotion should give us the emotion. Again, "The simulation of an emotion," says Darwin, "tends to arouse it in our minds." "There is reason to suspect," he says further, "that the muscular system requires some short preparation or some degree of innervation before being brought into action." This principle, laid down by the psychologist and scientist, has been followed by a number of actors in anticipation of some of their great scenes. Among those who adopted this method are Macready and Baron. The noted French actor of the early part of the 18th century prepared himself in this way before going on the stage in a scene of great excitement. "Il se battait les flancs pour se passionner; il apostrophait avec aigreur et injurait tous ceux qui se présentaient a lui, valets et camarades de l'un et de l'autre sexe." Macready had much the same practise. When he was playing The Merchant of Venice, he was in the habit of shaking a ladder violently in order to prepare himself for the dramatic scene with Tubal. Mr. Archer tells of a player who aroused himself by beating the property man. I will digress enough to finish this incident. It was understood that the actor would apologize after the conclusion of the drama and give the fellow a shilling for his pains. One night there was a poor house. In the wings the property man stood waiting for the ordeal, but the actor shook his head and whispered, "Not tonight, my good fellow, the treasury won't stand it." I cannot think that this kind of action for the purpose of arousing one's self for a scene of excitement is desirable even for the stage.

"It is difficult," admits James, "for us to produce in cold blood the total and integral expression of any one emotion because the number of parts modified is immense. We may catch the trick in the voluntary muscles, but we fail in the skin, glands, heart, and other viscera." If the actor fails to get a proper coöperation of all parts concerned, he is too likely to present a scene "full of sound and fury and signifying nothing." 
We know, however, that many players follow another and what seems to me a better method. They wait in the wings to receive their cue for entrance, and follow intently the development of the scene of which they are soon to become a part. It is said that Mrs. Siddons while behind the scenes fixed her mind on those disastrous events which call forth the mingled feelings of wounded friendship, disappointed ambition, and maternal tenderness as she appears in the third act of King John and exclaims,

"Gone to be married! Gone to swear a peace!"

The mere contemplation of those distressing circumstances, without the aid of any mechanical action as a preparation, awakened in her the appropriate spirit and enabled her to present what the critics considered a magnificent impersonation. Furthermore, concentration of thought upon the character and events seems to be the method of Forbes-Robertson. "When working in earnest," he says, "I admit only two strata: one stratum, the part, the creature I am for the time; the other, that part of my mind which circumstances and surroundings compel me to give up to all things coming under the head of mechanical execution." When you see him in Hamlet, you know he plays with emotion but you realize that he always retains the power of guiding and correcting the feeling whenever it grows too impetuous. As I think of the beauty of his impersonation of the Prince of Denmark, I am inclined to doubt that an actor, rousing himself for the tragic scenes by the means used by Macready and Baron, could produce on a modern audience that hears Shakespeare the abiding impression that Forbes-Robertson leaves upon the mind. His action at the burial of Ophelia in comparison with that of any actor that I have ever seen in this part is markedly subdued, but the restraint not only does not detract but it enhances the profound effect. The theatre is the place where we expect action more than we do in the speaker, but even here we are coming to reverence that actor who in the very "torrent, tempest and whirlwind of his passion acquires and begets a temperance that gives it smoothness."

Has there not been a similiar development in the history of Public Speaking? When we turn back the pages to the earliest times, we find that the orations are characterized by strong feeling and doubtless they were accompanied by the free action that goes with emotional experience. Men talked about themes which sprang up out of what James calls the coarser emotions. They addressed 
the public less frequently than modern speakers, but they spoke on such vital subjects that the primary emotions were stirred. At the time of Corax speaking must have been in a childlike stage. Men spoke for the rightful possession of houses and land. Oratory was a practical art. When Cicero was at the height of his power, the purpose of speaking had changed. It was now a fine art and became ornate in style and manner. Copiousness ran into verbosity, sound was as important as sense, grace of gesture was an end in itself, and the subject was sacrificed to personal vanity. In short, oratory had passed into the self-conscious stage. There were, of course, examples of what I have called the first and third stage and they have been picked out and commended; and there have been various fluctuations from one stage to another in different periods and different countries; but on the whole there has been a gradual drift toward a more mature stage where feeling is present merely as the servant of the intellect.

Let us consider the development attained in England. In his Modern Parliamentary Eloquence Lord Curzon raises this question, ${ }^{6}$ Is the orator greatly assisted by grace of manner, voice, and action, and is he correspondingly handicapped by uncomely and ignoble appearance, harsh accents, and inelegant gestures. He says that in the case of Chatham, Gladstone, O'Connell, and Bright much was gained by the splendor and harmony of their physical endowments. On the other hand, Burke was angular and awkard in his gestures, Pitt sawed the air with his arm like a windmill, Grattan indulged in violent gestures and swayed his body to and fro, Peel put his hands under his coat-tails, and Macaulay was ungainly in action. Lord Curzon comes to this conclusion: first, that all attempts to make a study of action, manner, or even delivery have been abandoned; secondly, that as speaking becomes less dramatic and more businesslike, even unstudied action falls every day into greater disuse. In the British Parliament a speaker stands almost motionless. His hands may cling to the lapel of his coat, or toy with a pince-nez. In all probablility his most violent action would be a mild castigation of the brass-bound box in front of him. Gestures of any sort are dying out. Here is Curzon's description of Asquith, "There is no gesticulation, no abandonment, no flash or glow, but the case is stated, argued, and proved with a force that is almost stunning." Curzon believes that there is no reason to deplore the cessation of fine speaking. Its practise in the passage of 
time has taken on different and less ambitious forms in consonance with the more practical spirit of the age. He thinks that at the present time it would be quite impossible for Canning to point to war ships in the harbor and say: "You well know, gentlemen, how soon one of these stupendous masses, now reposing on those shadows in perfect stillness, how soon upon call of patriotism or necessity, it would assume the likeness of an animated thing instinct with life and motion; how soon it would ruffle, as it were, its swelling plumage, how quickly it would put forth all its beauty and bravery, collect its scattered elements of strength and awaken its dormant thunder." "Imagine," says Lord Curzon, "the effect of this or of some ancient masterpiece of oratory delivered to the English Parliament!"

What is the status of action and emotional speaking in our own country? Sometime ago you doubtless read an article, I think it was in the Nation, which declared that it would be impossible for even Webster himself to hold the interest of the Senate today with an introduction so elaborate as that about the mariner or with a conclusion so rhetorical as his apostrophe to the standard full high advanced. Colonel Higginson tells an incident that illustrates the change as he saw it in 1898. An old politician had been absent from his home town for many years. In the days of his prime he had been noted as a model orator. Upon his return it was but natural that he should be asked to address the college assembly. He responded with a speech after the order of those orations that were once so famous and was greeted by the students with courteous applause. The professor who sat next to Mr. Higginson remarked at the close of the session, "Colonel Higginson, is the change in me or in the speaker?" "Curiously enough," said the Colonel, "I was thinking the same thing myself." They reached the conclusion that the orator had not changed in the thirty years of his absence but that public speaking in that time had been pitched in a much more natural key. Colonel Higginson did not enter into the reason for the change. It may have been the result of a number of forces, but one, I think is worthy of special notice in this connection. This is the scientific method of inquiry and treatment. "In the beginning of the nineteenth century," says President Eliot, "this method was known to but very few, but it has become indispensable in all fields of inquiry including psychology, philanthrophy, and religion." This method of investigation has 
had an influence also upon public speaking. The desire for pure knowledge has tended to throw into the background the emotional element and to place the intellect as the dominant feature in our public addresses. When we discuss even vital themes nowadays we consider them in a different way and with much less emotional demonstration than was used fifty years ago. When the woman suffrage question was beginning to receive attention, there was much elaboration of the justice of the cause, but recently speakers have abandoned the appeal to sentiment as vague and unsatisfactory and have made plain statements of woman's qualification for the ballot. This change of treatment is bound to bring a more subdued form of action. The same modification is noticeable in the speeches on the prohibition problem. Some years ago orators who spoke on this theme amplified the woes of the drunkard's family and denounced King Alcohol. But speakers are not treating the subject in this way now. Even the orations in the college contests show evidence of intelligent investigation. They present authoritative statements about the effect of alcohol upon the mind and body of the drinker and about the influence of the liquor traffic upon social and economic conditions. By the application of scientific methods in the treatment of their themes, speakers have been able to advance the suffrage and prohibition movements more much rapidly than the speakers who relied upon emotional appeal.

At an interstate contest a short time since two speakers attracted my attention. In one the intellect seemed to control and the emotion rarely if ever gained the ascendency. In the other the emotion seemed uppermost, although the speaker was not without thought. One of the judges, an attorney somewhat prominent in the state, declared that the man who was so emotional was out of date. When the average judgment was revealed it was found that the man who had controlled his feeling and who had deliberate action and convincing thought was given an advantage over the other speaker.

From Congress down to the college contest has there not been a drift toward a kind of speaking in which the intellect controls and the feeling and action are subdued and secondary? Webster and Everett, the models of their day, have given place to Lincoln. Are men like Sunday and Bryan the ideal speakers of the time? Darrow said to Bryan in the words of a recent poet:

"You're head of the party before you are ready; A leader should lead with thought." 
I am inclined to think that the teachers of Public Speaking would select Hughes or Wilson or some one in whom intelligence is the dominant element.

Again, what has happened in the development of our own profession in the last twenty-five years or less? There was a time when speaking was primarily a fine art. As a course of study it included Rhetoric, Literature, and Philosophy. Its purpose was to please and to present the beautiful. Very naturally emphasis drifted from the substance to the form, and artificiality took the place of art. How long the profession remained in this self-conscious stage, what schools fought it and what institutions fostered it,- these are questions apart from our purpose. At any rate, not very long ago there came an awakening. Teachers began to see that emotional speaking was not meeting the requirements of the practical age in which we live, and they accordingly established departments of Public Speaking. They realized that their profession, though it had to do with what may well be regarded a fine art, had, for the great mass of people, a very practical aspect. They saw that students of the colleges and universities were not going into active life after graduation to move people through appeals to emotion but that they would mould society, if they influenced it at all, through the application of intelligence to their speaking. In other words, they felt the influence of the scientific method of inquiry and treatment and they accordingly shaped their courses in Public Speaking to meet the practical needs of a practical age.

In bringing together the ideas of our discussion, I would say that the individual passes through a gradual development from a stage in which feeling is the dominant element and thought subordinate to a stage in which the intellect with growing power controls even the strongest emotion. As we survey the progress of races and nations toward civilization, we see that their acting and speaking tend from a stage of almost childish abandon to one of mature deliberation. In England and the United States at present the scientific method of inquiry and treatment and the passion for pure knowledge have changed the handling of nearly all themes which public speakers are called upon to discuss, and the result has been a pretty general recognition of a form of speaking characterized by subdued gesture and emotion and by an intellectual conviction that is almost irresistible. 